\title{
Impact of Salinity on Germination and Seedling Growth of Four Cool-Season Turfgrass Species and Cultivars
}

\author{
Hazim Serkan Tenikecier, Ertan Ates* \\ Tekirdag Namik Kemal University, Agriculture Faculty, Field Crops Department, Tekirdag-Turke
}

Received: 30 August 2021

Accepted: 8 October 2021

\begin{abstract}
Salinity is the main environmental factor accountable for decreasing crop productivity and turf quality worldwide. This study was carried out to determine and compare the salinity (sodium chloride, $\mathrm{NaCl}$ ) tolerance in newly developed eight cultivars of four cool-season turf grass species (perennial ryegrass, slender creeping red fescue, tall fescue and Kentucky bluegrass) at germination and seedling stage. All experiments were arranged as randomized plots design with three factors (species, cultivar and salinity level) and four replications. The obtained results showed that the seed germination of perennial ryegrass, slender creeping red fescue, tall fescue and Kentucky bluegrass cultivars were highly affected by the highest level of salinity $(200 \mathrm{mM} \mathrm{NaCl})$. Statistically significant were observed differences among $\mathrm{NaCl}$ levels for root fresh mass, shoot fresh and dry mass, water retention capacity, relative water content, tolerance index and $\mathrm{K}^{+} / \mathrm{Na}^{+}$ratios of cultivars. Based on their tolerance index (TI), five cultivars, 'Ringles' perennial ryegrass, 'Abercharm' slender creeping red fescue, 'Prafin' Kentucky bluegrass, 'Fesnova' and 'Golden Gate' tall fescue demonstrated good salt tolerance. The tolerance indexes of these cultivars were supported by the $\mathrm{K}^{+} / \mathrm{Na}^{+}$ratios. The cultivars 'Ringles', 'Abercharm', 'Prafin', 'Fesnova' and 'Golden Gate' exhibited potential salt tolerance and could compete with other cool-season turfgrass varieties regarding productivity under salt stress.
\end{abstract}

Keywords: germination, seedling growth, tolerance index, turfgrass, salinity

\section{Introduction}

Salinity is one of the abiotic stresses and it is a big problem of both irrigated and non-irrigated turfgrass areas in several parts of the world, with a predominance in arid and semi-arid regions [1]. Especially, being near the coast should never restrict to grow turf of the high

*e-mail: ertan_ates@hotmail.com quality. Even in locations that are distant from the sea, salinity can be a problem caused by rising levels of salt in groundwater and an increasing reliance on recycled water for irrigation. Salinity also affects the verges of winter-salted roads and it inhibits the growth of turfgrass species [2].

Most cool-season turfgrass species do not establish or survive long in highly saline areas, allowing salttolerant weeds to invade. Salinity limits plant growth and productivity through the toxic effects of sodium $\left(\mathrm{Na}^{+}\right)$ 
and chloride $\left(\mathrm{Cl}^{-}\right)$ions, which leads to ionic imbalances, osmotic and oxidative stress [3]. Salinity tolerance is a complex trait, governed by several physiological and biochemical parameters and these parameters greatly influence the normal growth and development of plants [4]. Salinity makes it difficult for the roots to take up water due to the decreased osmotic potential [5]. Plants may have difficulty withdrawing water from what appear to be moist soils. A build-up of salt in the leaves, especially old leaves, can lead to necrosis. The overall effect on the plant depends on the rate of new growth compared with the rate of leaf necrosis. High $\mathrm{Na}^{+}$and $\mathrm{Cl}^{-}$concentrations in the soil can affect the uptake of other nutrients, e.g., nitrogen, phosphorus, potassium and, magnesium, which are essential for plant growth [6]. Besides, salinity accelerates the production of active oxygen radicles, such as $\mathrm{H}_{2} \mathrm{O}_{2}$ (hydrogen peroxide), $\bullet \mathrm{O}_{2}$ (superoxide), ${ }^{1} \mathrm{O}_{2}$ (singlet oxygen), and $\cdot \mathrm{OH}^{-}$(hydroxyl radicle), which can damage or even kill plants [7].

Cool-season turfgrass species and other species vary widely in their tolerance to salts in soil and irrigation water $[5,8]$. In most plants, salt tolerance is lowest at germination and during early seedling establishment [9]. Germination failures on saline soils are often the results of high salt concentrations in the seed planting zone because of upward movement of soil solution and subsequent evaporation at the soil surface. These salts interfere with seed germination and crop establishment. Lower levels of salinity delayed germination whereas higher levels in addition, reduced the final percentage of seed germination [10]. Salt tolerance levels can also change with soil and environmental conditions. Minimizing the salt stress on plants, particularly during early development, promotes successful establishment and growth [11]. Salt tolerance of any individual species is demonstrated as the ability to maintain an optimal physiological and biochemical equilibrium under $\mathrm{NaCl}$ treatment [3]. In addition to salinity tolerance, tolerance to heat and drought stress is required, because much of the salinized area around the world is found in hot and dry regions [12].

Nevertheless, the new cultivars of cool-season turfgrass species are constantly being developed by breeding companies in Europe, USA and etc. [13]. These cultivars tolerance to abiotic and biotic stresses at different climates must be known for turf management. Besides, the relative salt tolerance among most of the widely used new developed these cultivars has not been adequately studied and it is important to determine cultivars which can have a chance in saltaffected lands [14]. Because of this reason use of salttolerant cultivars offers a useful approach for increasing turfgrass performance. The first step in the program of identification and screening for salinity tolerance in turfgrass species and cultivars are a conduct a germination examination [15]. Literature suggests that in the seedling stage varieties of perennial ryegrass (Lolium perenne L.), slender creeping red fescue (Festuca rubra L. ssp. trichophylla Gaud.), tall fescue
(F. arundinacea Schreb.) and Kentucky bluegrass (Poa pratensis L.) show different tolerance of salinity stress. Because of that, screening and breeding cool-season turfgrass varieties that are salt tolerant during both seed germination and vegetative growth becomes important [16]. Besides, the need for salinity tolerant turfgrasses is increasing because of the increased use of effluent or other low-quality waters for turfgrass irrigation. This study, therefore, was carried out to determine and compare salinity (sodium chloride, $\mathrm{NaCl}$ ) tolerance in newly developed cultivars of four cool-season turf grass species (perennial ryegrass, slender creeping red fescue, tall fescue and Kentucky bluegrass) at germination and seedling stage.

\section{Materials and Methods}

\section{Materials}

Germination experiment was carried out in 2017 at the Department of Field Crops, Faculty of Agriculture, University of Tekirdag Namik Kemal in Turkey. Greenhouse experiments were carried out in 20172018 at same department. Salt tolerance was screened between two cultivars of four cool-season turfgrass species: (I) Perennial ryegrass: cv. 'Ringles' and cv. 'Sun', (II) Slender creeping red fescue: cv. 'Abercharm' and 'Spartan 2', (III) Tall fescue: cv. 'Fesnova' and cv. 'Golden Gate', (IV) Kentucky bluegrass: cv. 'Prafin' and cv. 'Heatmaster'. The certified seed of these cultivars belongs to Semillas Fitó S.A.U in Barcelona (Spain). Before experiments, viability of the seeds was tested by tetrazolium (2, 3, 5-triphenyltetrazolium chloride) test (TTC test) [17]. All experiments were arranged as randomized plots design with three factors (species, cultivar and salinity level) and four replications.

\section{Methods}

\section{Laboratory Experiment}

For surface sterilization, seeds were soaked in $2 \%$ $\mathrm{NaClO}$ (sodium hypochlorite) for 15 minute and rinsed with sterile water four times and then quickly dried with a sterile paper tissue. Subsequently, four replicates of twenty-five viable seeds for each cultivar of four species were placed on one layer of sterile 'germ test' paper (neutral $\mathrm{pH}$ ) in closed sterile petri dishes (diameter of $15 \mathrm{~cm}$ ) and moistured with $10 \mathrm{ml}$ of deionized water at five concentrations of $\mathrm{NaCl}$ (Merck 106404 for analysis EMSURE ${ }^{\circledR}$ ACS, ISO, Reag. Ph Eur), namely 0 (control), 50, 100, 150 and $200 \mathrm{mM}$ [5, 18]. Petri dishes were sealed with parafilm to prevent evaporation. According to the results of preliminary studies and standard seed laboratory protocols for perennial ryegrass, slender creeping red fescue, tall fescue and Kentucky bluegrass seed germination tests 
$[17,19,20]$ were conducted for forty-five days when no further germination was observed [21]. Tests were then incubated at $20 \pm 2.0^{\circ} \mathrm{C}$ under $1.63 \mathrm{Wm}^{-2}$ of fluorescent lighting at a $12 \mathrm{~h}$ light $/ 12 \mathrm{~h}$ dark diurnal cycle. Seeds were considered to have germinated when their radicles have emerged, after which the number of seeds germinated was recorded. During testing, contamination was not found. In salinity stress conditions, because of slow germination of seeds, germination tests were conducted over a longer period (forty-five days) than foreseen in the rules of $[17,19,20]$. Final germination percentage is described by FGP $(\%)=100 \frac{\Sigma n}{45}[22]$.

\section{Greenhouse Experiments}

In each year (2017 and 2018), eight seeds of each cultivar were initially planted in each plastic pot (each replication consisted of twenty pots, $18 \mathrm{~cm}$ high $\mathrm{x} 16$ $\mathrm{cm}$ in diameter) filled with an $1800 \mathrm{~g}$ heat-sterilized $\left(95^{\circ} \mathrm{C}, 72 \mathrm{~h}\right)$ soil consisting of $60 \%$ sand, $25 \%$ silt, and $15 \%$ clay, and after the emergence of all the seedlings, four seedlings were allowed to growth in each pot [8]. To prevent resistance in the pots, the mortar soil was placed into polyethylene bags [23]. Pots and bags were sterilized with $2 \% \mathrm{NaClO}$ for 15 minute and rinsed with sterile water four times. The base nutrient solution was applied in $100 \mathrm{ml}$ to the all pots. The base nutrient solution consisted of quarter-strength Hoagland's solution, except for calcium and magnesium, which were at full strength. This concentration was according to the protocol for forage production under salt stress [24]. All fertilizers used were analytical reagent grade and their concentrations in the solution were as: $0.25 \mathrm{mM}$ potassium dihydrogen phosphate $\left(\mathrm{KH}_{2} \mathrm{PO}_{4}\right)$, $1.25 \mathrm{mM}$ potassium nitrate $\left(\mathrm{KNO}_{3}\right), 5.0 \mathrm{mM}$ calcium nitrate $\left(\mathrm{Ca}\left(\mathrm{NO}_{3}\right)_{2} \cdot 4 \mathrm{H}_{2} \mathrm{O}\right), \quad 2.0 \mathrm{mM}$ magnesium sulfate $\left(\mathrm{MgSO}_{4} 7 \mathrm{H}_{2} \mathrm{O}\right), 11.3 \mu \mathrm{M}$ boric acid $\left(\mathrm{H}_{3} \mathrm{BO}_{3}\right)$, $2.3 \mu \mathrm{M}$ manganese (II) chloride $\left(\mathrm{MnCl}_{2} \cdot 4 \mathrm{H}_{2} \mathrm{O}\right)$, $0.2 \mu \mathrm{M}$ zinc sulfate $\left(\mathrm{ZnSO}_{4} \cdot 7 \mathrm{H}_{2} \mathrm{O}\right), 0.08 \mu \mathrm{M}^{2}$ copper sulfate $\left(\mathrm{CuSO}_{4} \cdot 5 \mathrm{H}_{2} \mathrm{O}\right), 0.004 \mu \mathrm{M}$ ammonium molybdate tetrahydrate $\left(\left(\mathrm{NH}_{4}\right)_{6} \mathrm{Mo}_{7} \mathrm{O}_{24} \cdot 4 \mathrm{H}_{2} \mathrm{O}\right)$ and $30.0 \mu \mathrm{M}$ ferric-EDTA (Fe-EDTA). Concentrations of $\mathrm{NaCl}$ (0, 50, 100,150 and $200 \mathrm{mM}$ ) were applied in $100 \mathrm{ml}$ of water after emergence of each cultivar, and all pots were irrigated to field capacity. Salinity level was measured twice a week throughout the experimental duration with EC meter and maintained with the addition of proper quantity of $\mathrm{NaCl}$ solution. Control pots were irrigated with distilled water. After the targeted salinity levels were achieved, the irrigation water depending on field capacity was applied for a period of seven weeks (March 07 to April 26 at each year) at greenhouse condition [25]. Fifty days after emergence, seedlings were taken by gentile washing the soil, and each seedling were separated into roots and shoots [16]. Then, the root and shoot fresh mass (RFM and SFM, mg per plant) were determined. Shoot samples were oven-dried at $65^{\circ} \mathrm{C}$ for $48 \mathrm{~h}$, to determine dry mass (SDM, mg per plant).
The water retention capability of the shoot was calculated using the following formula: Retention capability $(\mathrm{RCS})$ of shoot $(\mathrm{mg})=(\mathrm{SFM}-\mathrm{SDM}) / \mathrm{SDM}$ [26]. Relative water content (RWC) as percentage of SFM was calculated the following formula: RWC (\%) = SFM-SDM/SFM x 100 [10]. Furthermore, a tolerance index (TI) was calculated for each cultivar of species; i.e., shoot dry mass (SDM) was calculated by adopting the following formula [27]: TI = SDM in salinity stress/SDM in control x 100 .

\section{Chemical Analyses}

The oven-dried samples were ground to small $(\leq 1 \mathrm{~mm})$ pieces and $15 \mathrm{mg}$ of this was transferred to a digestion flask $(25 \mathrm{ml})$ containing an acid mixture of nitric acid $\left(\mathrm{HNO}_{3}\right)$ and perchloric acid $\left(\mathrm{HClO}_{4}\right)$, in the ratio $3: 1(\mathrm{v} / \mathrm{v})$. The flask was heated gently over a sand bath. The cooled digest was then diluted by adding distilled water and the volume was made up as required. The potassium $\left(\mathrm{K}^{+}\right)$and $\mathrm{Na}^{+}$concentrations were determined using a flame photometer (Shanghaiprecision and scientific instrument Co., Ltd., 6400 A type) following the methods described by [10], then $\mathrm{K}^{+} / \mathrm{Na}^{+}$ratios of shoots were calculated. All samples were analyzed in triplicate.

\section{Data Analyses}

Data were analyzed using analysis of variance (ANOVA) (TARIST statistical computer package). There were no significant differences at $P>0.05$ in the year and interactions when comparing the year of greenhouse study or salinity levels. The percentages were subjected to arcsine transformation. Same program was used for the comparison test (Fisher's Least Significant Difference, LSD) of the means from the two years and Standard Deviation (SD) was calculated.

\section{Results and Discussion}

\section{Effect of Salinity on Seed Germination}

The obtained results showed that the seed germination of perennial ryegrass, slender creeping red fescue, tall fescue and Kentucky bluegrass cultivars were highly affected by highest level of salinity $(200 \mathrm{mM}$ $\mathrm{NaCl})(P<0.01$, Table 1$)$. FGP of both species 'perennial ryegrass' (75.2\%) and 'Kentucky bluegrass' (75.4\%) significantly decreased in same salinity level. However, $\mathrm{NaCl}$ treatment resulted in decreasing the FGP in the perennial ryegrass and Kentucky bluegrass cultivars as compared to slender creeping red fescue and tall fescue cultivars. The lowest FGP was determined from perennial ryegrass cultivar 'Sun' with $200 \mathrm{mM} \mathrm{NaCl}$ level. Among tested eight cultivars of four turfgrass 


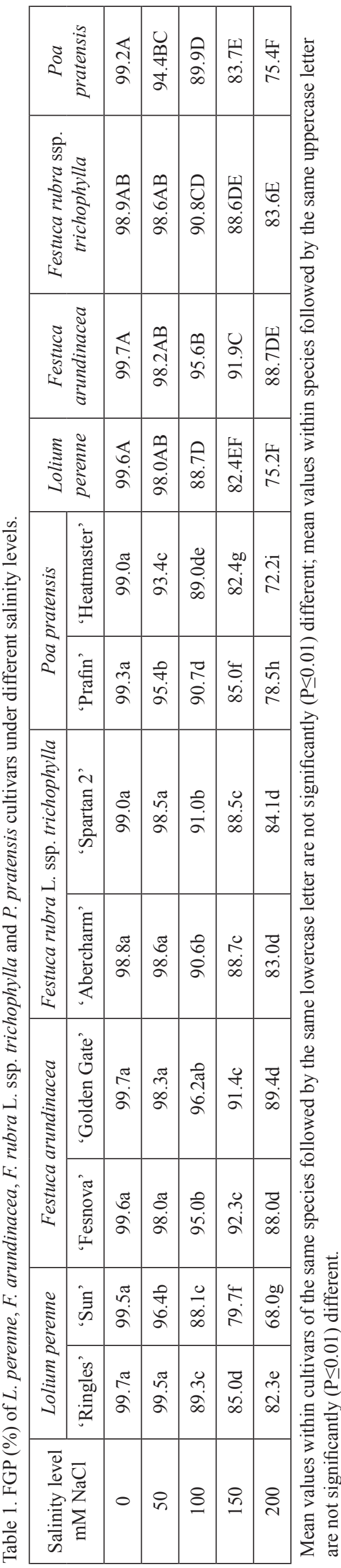

species 'Golden Gate' (89.4\%) and 'Fesnova' (88.0\%) showed higher FGP in this salinity concentration. Genetic variability within a species offers a valuable tool for studying mechanism of salt tolerance. One of these mechanisms depends on the capacity for osmatic adjustment that allows growth to continue under saline conditions. With increasing salinity there was a decrease in germination of seeds in the cultivars. Inhibition of germination due to salinity has been reported earlier $[5,6]$. It is suggested that decrease in seed germination under saline stress is attributed to decrease water uptake followed by limited hydrolysis of nutrient reserves from storage tissue as well as due to impaired translocation of nutrient reserves from storage tissue to developing embryo axis [10]. When salt-stressed, turfgrasses can suffer from indirect water stress, causing a block in seed germination. An increasing $\mathrm{NaCl}$ concentration is likely caused by a decrease in the water potential gradient between seeds and their surrounding media. Seed germination is negatively affected by salinity stress, either osmotically through reduced water absorption or ionically through $\mathrm{Na}^{+}$and $\mathrm{Cl}^{-}$accumulation, resulting in an imbalance in nutrient uptake and toxicity effects [18]. Sahiade and Boelt [28] emphasized that tall fescue is a cool-season turfgrass with a moderate to high salinity tolerance, and it possess a wide range of variation in salinity tolerance. Contrary to our results, BorawskaJarmułowicz et al. [16] reported that the germination of perennial ryegrass to be relatively the most salt-tolerant than Kentucky bluegrass. Sheikh-Mohamadi et al. [22] stated that germination of seeds should occur uniformly for a successful establishment of turfgrass seedlings and high FGP is indicator that there is a high potential for successful establishment. Turk and Alagoz [9] reported increased salt concentrations caused decreased the germination rate of tall fescue. Present findings coincide with those earlier ones.

\section{Effect of Salinity on Root and Shoot of Seedlings}

Among four cool-season turfgrass species and their cultivars, differences were observed in the root fresh mass, shoot fresh and dry mass (Table 2). Increasing $\mathrm{NaCl}$ concentration resulted in a significant decrease in root fresh mass, shoot fresh and dry mass $(P<0.01)$. It was noticed that salinity had more negative effects on root fresh mass, shoot fresh and dry mass of slender creeping red fescue, Kentucky bluegrass and perennial ryegrass plants than on tall fescue. Concentration of $200 \mathrm{mM} \mathrm{NaCl}$ resulted in significantly lightweight shoots (39.6 mg of shoot fresh mass per plant and 10.0 $\mathrm{mg}$ of shoot dry mass per plant) of slender creeping red fescue and root dry mass (14.6 mg per plant) of Kentucky bluegrass. At same salinity level, Kentucky bluegrass cultivar 'Heatmaster' had lower root fresh mass than among cultivars of other species while slender creeping red fescue cultivars 'Abercharm' and 'Spartan 2' had lower shoot fresh mass and shoot dry mass than other cultivars of species. Massahi et al. [29] 


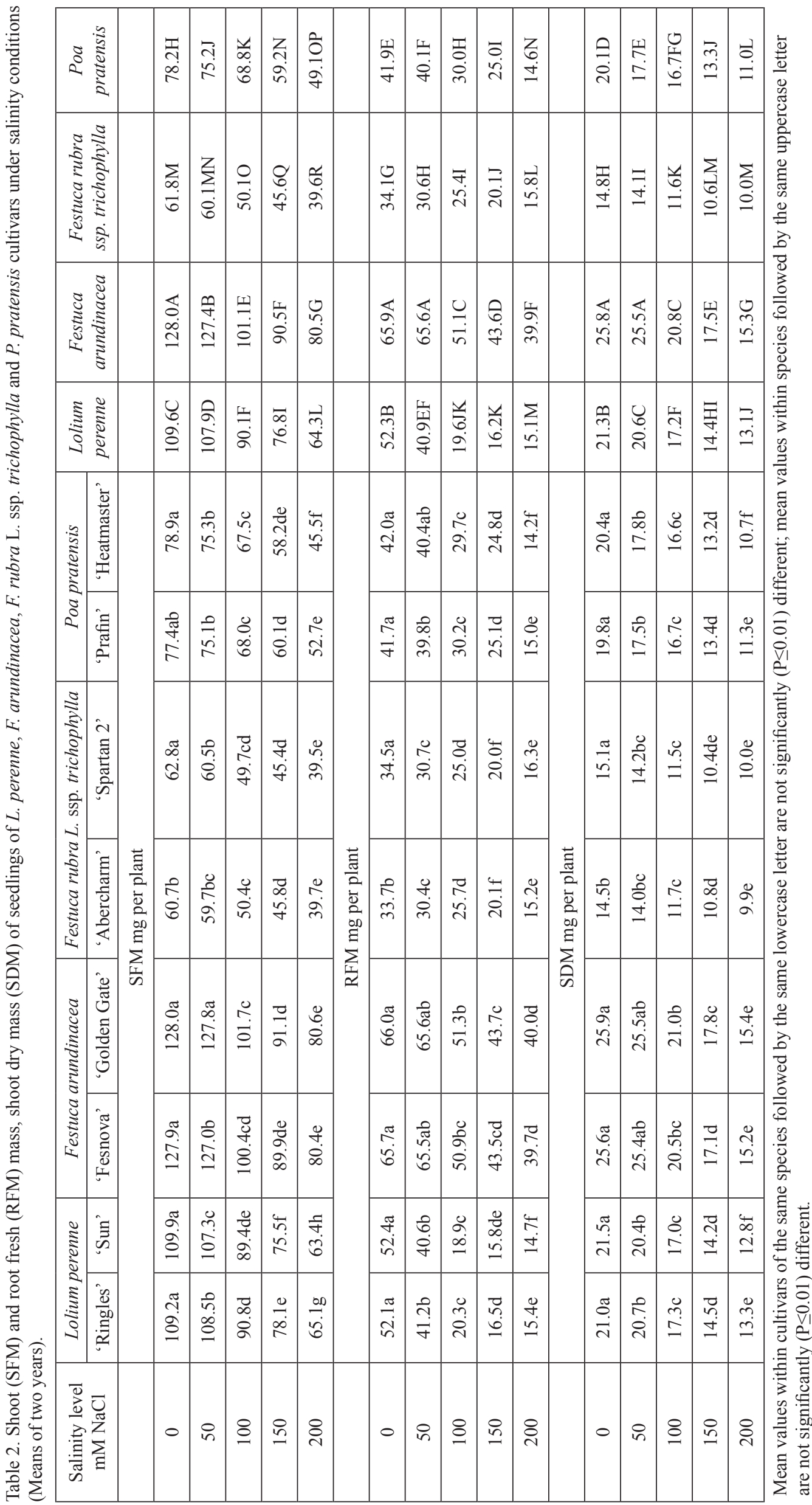







reported that lawn quality of tall fescue was unaffected by saline irrigation at an EC of $12.0 \mathrm{dS} \cdot \mathrm{m}^{-1}$ for 210 days. Wheatgrass (Agropyron cristatum L.), perennial ryegrass, red fescue (F. rubra L.), and switchgrass (Panicum virgatum L.) were also classified 'moderately tolerant' together with tall fescue. Among the coolseason turfgrasses, the authors only rated alkali grass (Puccinellia spp.) as 'tolerant': able to grow at salt levels equivalent to $>10 \mathrm{ds} \mathrm{m}^{-1}$. Salt stress involves osmotic and ionic stresses, and the suppression of growth is directly contingent on the total soluble salt concentration and soil osmotic potential. The detrimental effect can be seen at the whole-plant level as plant death or decreased productivity [18]. According to Borawska-Jarmułowicz et al. [16] and Souri and Tohidloo [30], the fresh mass and dry mass of seedlings were significantly increased under salinity conditions. Our data showed that under this salinity level the root mass of cultivars of four species reduced. Other values were similar to those designated by researchers $[1,8,10,31,32]$.

\section{Effect of Salinity on RCS, RWC and TI of Shoot of Seedlings}

Statistically significant $(P<0.01)$ were observed differences among $\mathrm{NaCl}$ levels for RCS, RWC and TI of shoots of seedlings in perennial ryegrass, tall fescue, slender creeping red fescue and Kentucky bluegrass cultivars (Table 3). TI of the species and cultivars significantly decreased in salt stress. When compared four turfgrass species, the lowest TI was calculated in the Kentucky bluegrass (54.8\%) in $200 \mathrm{mM} \mathrm{NaCl}$ level, whereas the lowest RCS (2.9 mg) and RWC (74.3\%) were determined in the same species in control treatment. The tall fescue cultivars 'Golden Gate' and 'Fesnova' exhibited higher values than the other cultivars for RCS of shoot (4.2-4.3 mg) under $200 \mathrm{mM}$ salinity level. However, the cultivars showed diversity in RWC under salt stress. The Kentucky bluegrass cultivars showing a low RWC for shoot in control treatment were cultivar 'Heatmaster' (74.1\%) and cultivar 'Prafin' (74.4\%). These results were distinct with Ates and Tekeli [10]. They reported that the RWC of shoot were not affected in salinity treatments whereas Negrão et al. [33] stated that the water content and osmotic potential of plants become more negative with an increase in salinity, whereas turgor pressure increases with increasing salinity. Hniličková et al. [34] reported that the osmotic potential decreased with increasing $\mathrm{NaCl}$ concentration, while RWC decreased did not take place until $200 \mathrm{mM}$ $\mathrm{NaCl}$. A greater decline in osmotic potential compared with the total water content led to turgor maintenance in plants under progressive or prolonged salinity stress [35]. Soni et al. [36] emphasized that the water content was decreased by salinity stress conditions, but Gebauer et al. [37] reported that the leaves of salttreated plants accumulated more water than leaves of control plants. In the study carried out by Lin and Qian [23], they were determined that TI was higher in low




salt concentrations, as salt level increased TI decreased significantly, which is similar to the present findings.

\section{Effect of Salinity on $\mathrm{K}^{+} / \mathrm{Na}^{+}$Ratios in Shoot Dry Mass}

The $\mathrm{K}^{+} / \mathrm{Na}^{+}$ratios in shoots dry mass were also significant different $(P<0.01$, Table 4$)$. The $\mathrm{K}^{+} / \mathrm{Na}^{+}$ratios were decreased with the increase of $\mathrm{NaCl}$ concentrations. The $200 \mathrm{mM} \mathrm{NaCl}$ treatment had the lowest $\mathrm{K}^{+} / \mathrm{Na}^{+}$ratio of 1.5 (ranging from 1.5 to 2.2 for all cultivars) in shoot dry mass of 'Prafin' cultivar of Kentucky bluegrass. The possible mechanisms of salt tolerance in plants include the following: (a) the uptake of no or little salt into the plant, (b) tissue tolerance, (c) the accumulation of salt in vacuoles without any physiological interference, (d) ion discrimination (e.g., $\mathrm{K}^{+}$, sodium $\left(\mathrm{Na}^{+}\right)$, chloride $\left(\mathrm{Cl}^{-}\right)$, and sulfate ( $\left.\mathrm{SO}^{-}\right)$) during root uptake and translocation in plant shoots, and (v) the use of different biochemical processes, such as enzyme, hormone, or antioxidant production. One or more of these mechanisms may be responsible for the observed variations in the salt tolerance of plants with different genotypes and from different species. The $\mathrm{K}^{+} / \mathrm{Na}^{+}$ratio has been established as a criterion by scientists to determine if a plant has salt tolerance. Thus, cultivars that maintain higher $\mathrm{K}^{+}$ $\mathrm{Na}^{+}$ratios are considered salt tolerant [38]. Evelin et al. [39] reported that regulating $\mathrm{K}^{+}$uptake and preventing $\mathrm{Na}^{+}$entry and the efflux of $\mathrm{Na}^{+}$from cells are common strategies used by plants to maintain desirable $\mathrm{K}^{+} / \mathrm{Na}^{+}$ ratios in the cytosol. Rodrigues [40] demonstrated that the maximum ratios of photosynthesis and plant growth occurred when the leaf $\mathrm{K}^{+} / \mathrm{Na}^{+}$ratios were between 1.0 and 2.0, which indicated that this parameter could be a good indicator in leaves for favorable $\mathrm{K}^{+}$homeostasis under high salinity conditions. The tall fescue cultivars and slender creeping red fescue cultivar 'Spartan 2' had $\mathrm{K}^{+} / \mathrm{Na}^{+}$ratios greater than 2.0. Besides, our results were distinct with Gebauer et al. [36]. They reported that the $\mathrm{K}^{+} / \mathrm{Na}^{+}$ratio increased as the salinity of the irrigation water increased for tall fescue cultivar 'Fawn' and perennial ryegrass cultivar 'Quartet'.

\section{Conclusions}

Salinity is one of the most important factors affecting turf of the high quality. The results from the different $\mathrm{NaCl}$ concentrations applied in four cool-season turfgrass species and cultivars can be summarized as follow: (a) Eight introduced turfgrass cultivars showed different adaptations for coping with different salinity levels. (b) Based on their tolerance index (TI), five cultivars, 'Ringles' perennial ryegrass, 'Abercharm' slender creeping red fescue, 'Prafin' Kentucky bluegrass, 'Fesnova' and 'Golden Gate' tall fescue demonstrated good salt tolerance. (c) In addition, maximum ratios of photosynthesis and plant growth occurred when the $\mathrm{K}^{+} / \mathrm{Na}^{+}$ratios were between
1.0 and 2.0. The tolerance indexes of the these cultivars were supported by the $\mathrm{K}^{+} / \mathrm{Na}^{+}$ratios. (d) The cultivars 'Ringles', 'Abercharm', 'Prafin', 'Fesnova' and 'Golden Gate' exhibited potential salt tolerance and could compete with other cool-season turfgrass varieties regarding productivity under salt stress.

\section{Conflict of Interest}

The authors declare no conflict of interest.

\section{References}

1. ALAGOZ M., TURK M. Effect of different salt concentrations on the germination and seedling development of ryegrass (Lolium perenne L.). Euroasia Journal of Mathematics, Engineering, Natural and Medical Sciences, 7, 1, 2020.

2. ANONYMOUS. Turf for saline conditions. DLF Seed and Science, Worcestershire, UK. Available online: http:// www.dlf.com (accessed on 25.07.2021).

3. ROY S., CHAKRABORTY U. Screening of salttolerance potential of some native forage grasses from the eastern part of Terai-Duar grasslands in India. Tropical Grasslands-Forrajes Tropicales, 5, 129, 2017.

4. TEMEL S., KESKIN B., SIMSEK U., YILMAZ I.H. Performance of some forage grass species in halomorphic soil. Turkish Journal of Field Crops, 20, 131, 2015.

5. DEMIROGLU TOPCU G., OZKAN S.S. Effects of different salt sources and concentrations on germination parameters of barley (Hordeum vulgare L.) seeds. ISPEC Journal of Agricultural Sciences 4, 456, 2020.

6. PONARO C., BAROLO E., RIMI F., MACOLINO S., RICHARDSON M. Performance of various coolseason turfgrasses as influenced by simulated traffic in northeastern Italy. European Journal of Horticultural Science, 81, 27, 2016.

7. MWANDO E., ANGESSA T.T., HAN Y., LI C. Salinity tolerance in barley during germination-homologs and potential genes. Journal of Zhejiang University-Science B (Biomedicine \& Biotechnology), 21, 93, 2020.

8. ORAK A., ATES E. Resistance to salinity stress and available water levels at the seedling stage of the common vetch (Vicia sativa L.). Plant Soil and Environment, 51, 51, 2005.

9. TURK M., ALAGOZ M. Effects of salt stress on the germination of tall fescue (Festuca arundinacea Schreb.) seeds. Journal of Agricultural Faculty of Bursa Uludag University, 34, 317, 2020.

10. ATES E., TEKELI A.S. Salinity tolerance of Persian clover (Trifolium resupinatum var. Majus Boiss.) lines at germination and seedling stage. World Journal of Agricultural Sciences, 3, 71, 2007.

11. MCFARLAND M., PROVIN T., REDMON L., BOELLSTORFF D., PETERSON J., MCDONALD A., STEIN L., WHERLEY B., REYNOLDS C. Salinity and Boron Tolerance of Common Native and Introduced Plants in Texas. Texas A\&M AgriLife Extension, ESC-011, USA, pp. 11-14, 2018

12. YAMAZAKI K., ISHIMORI M., KAJIYA-KANEGAE H., TAKANASHI H., FUJIMOTO M., YONEDA J., YANO K., KOSHIBA T., TANAKA R., IWATA H., 
TOKUNAGA T., TSUTSUMI N., FUJIWARA T. Effect of salt tolerance on biomass production in a large population of sorghum accessions. Breeding Science, 70, 167, 2020.

13. DEMIROGLU G., GEREN H., KIR B., AVCIOGLU R. Performances of some cool season turfgrass cultivars in Mediterranean environment: II. Festuca arundinacea Schreb., Festuca ovina L., Festuca rubra spp. rubra L., Festuca rubra spp. trichophylla Gaud and Festuca rubra spp. commutata Gaud. Turkish Journal of Field Crops, 15, 180, 2010.

14. KOZŁOWSKA M., BANDURSKA, H., BRE'S W. Response of lawn grasses to salinity stress and protective potassium effect. Agronomy, 11, 843, 2021.

15. MEYER W.A., HOFFMAN L., BONOS S.A. Breeding cool-season turfgrass cultivars for stress tolerance and sustainability in a changing environment. International Turfgrass Society Research Journal, 13, 3, 2017.

16. BORAWSKA-JARMUŁOWICZ B., MASTALERCZUK G., GOZDOWSKI D., MAŁUSZYŃSKA E., SZYDŁOWSKA A. The sensitivity of Lolium perenne and Poa pratensis to salinity and drought during the seed germination and under different photoperiod conditions. Zemdirbyste-Agriculture, 104, 71, 2017.

17. AOSA. Rules for testing seeds, Vol. 1. Principles and procedures. Association of Official Seed Analyst, Washington D.C., USA, 2019.

18. DEMIROGLU TOPCU, G., OZKAN, Ş.S. Effects of different salt sources and concentrations on germination parameters of barley (Hordeum vulgare L.) seeds. ISPEC Journal of Agricultural Sciences, 4, 456, 2020.

19. AOSA. Rules for testing seeds, Vol. 2. Uniform blowing procedure. Association of Official Seed Analyst, Washington D.C., USA, 2016.

20. ISTA. International rules for seed testing (2018 Edition). Bassersdorf, Switzerland, 2018.

21. SHEN J.B., XU L.Y., JIN X.Q., CHEN J.H., LU H.F. Effect of temperature regime on germination of seed of perennial ryegrass (Lolium perenne). Grass and Forage Science, 63, 249, 2008.

22. SHEIKH-MOHAMADI M.H., ETEMADI N., NIKBAKHT A. Screening and selection of twenty Iranian wheatgrass genotypes for tolerance to salinity stress during seed germination and seedling stage. HortScience, 52, 1125, 2017.

23. LIN Y., QIAN Y. Mineral composition of Kentucky bluegrass under recycled water irrigation on golf courses. HortScience, 54, 357, 2019.

24. PECETTI L., ANNICCHIARICO P. Assessing and overcoming genetic trade-offs in breeding grazing-tolerant lucerne. Crop and Pasture Science, 68, 952, 2017.

25. NTOULAS N., VARSAMOS I. Performance of two seashore paspalum (Paspalum vaginatum Sw.) varieties growing in shallow green roof substrate depths and irrigated with seawater. Agronomy, 11, 250, 2021.

26. CLARKE J.M. Effect of leaf rolling on leaf water loss in Triticum ssp. Canadian Journal of Plant Science, 66, 885, 1986

27. KARGBO S.S., SHOWEMIMO F.A., PORBENI J.B.O., AKINTOKUN P.O. Response of rice genotypes to salinity under hydroponic conditions. Agro-Science, 18, 11, 2019.

28. SAHIADE S.R.G., BOELT B. Seed germination and seedling growth parameters in nine tall fescue varieties under salinity stress. Acta Agriculturae Scandinavica, Section B-Soil \& Plant Science, 70, 485, 2020.

29. MASSAHI S., NADERI D., PESSARAKLI M. Studying the effect of two biological fertilizers on salt tolerance of tall fescue (Festuca arundinacea Schreb.). Journal of Plant Nutrition, 41, 2210, 2018.

30. SOURI M.K., TOHIDLOO G. Effectiveness of different methods of salicylic acid application on growth characteristics of tomato seedlings under salinity. Chemical and Biological Technologies in Agriculture, 6, $1,2019$.

31. DEMIROGLU TOPCU G., CELEN A.E., KURU E., OZKAN S.S. A study on the effects of different $\mathrm{NaCl}$ concentrations on germination and early growing stage of tall fescue (Festuca arundinacea) and intermediate wheatgrass (Agropyron intermedium). Journal of Central Research Institute for Field Crops, 25, 219, 2016.

32. SHIADE S.R.G., BOELT B. Seed germination and seedling growth parameters in nine tall fescue varieties under salinity stress. Acta Agriculturae Scandinavica, Section B - Soil \& Plant Science, 70, 485, 2020.

33. NEGRÃO S., SCHMÖCKEL S.M., TESTER M. Evaluating physiological responses of plants to salinity stress. Annals of Botany, 119, 1, 2017.

34. HNILIČKOVÁ H., HNILIČKA F., MARTINKOVÁ J., KRAUS K. Effects of salt stress on water status, photosynthesis and chlorophyll fluorescence of rocket. Plant Soil and Environment, 63, 362, 2017.

35. STAVRIDOU E., WEBSTER R.J., ROBSON P.R.H. Novel Miscanthus genotypes selected for different drought tolerance phenotypes show enhanced tolerance across combinations of salinity and drought treatments. Annals of Botany, 124, 653, 2019.

36. SONI S., KUMAR A., SEHRAWAT N., KUMAR A., KUMAR N., LATA C., MANN A. Effect of saline irrigation on plant water traits, photosynthesis and ionic balance in durum wheat genotypes. Saudi Journal of Biological Sciences, 28, 2510, 2021.

37. GEBAUER J., EL-SIDDIG K., SALIH A.A., EBERT G. Tamarindus indica L. seedlings are moderately salt tolerant when exposed to $\mathrm{NaCl}$-induced salinity. Scientia Horticulturae, 103, 1, 2004.

38. AL-GHUMAIZ N.S., ABD-ELMONIEM E.M., MOTAWEI M.I. Salt tolerance and K/Na ratio of some introduced forage grass species under salinity stress in irrigated areas. Communications in Soil Science and Plant Analysis, 48, 1494, 2017.

39. AL-GHUMAIZ N.S., ABD-ELMONIEM E.M., MOTAWEI M.I. Mitigation of salinity stress in plants by arbuscular mycorrhizal symbiosis: current understanding and new challenges. Frontiers in Plant Science, 10, 470, 2019.

40. RODRIGUES C.R.F., SILVA E.N., FERREIRA-SILVA S.L., VOIGT E.L., VIÉGAS R.A., SILVEIRA J.A.G. High $\mathrm{K}^{+}$supply avoids $\mathrm{Na}^{+}$toxicity and improves photosynthesis by allowing favorable $\mathrm{K}^{+}: \mathrm{Na}^{+}$ratios through the inhibition of $\mathrm{Na}^{+}$uptake and transport to the shoots of jatropha curcas plants. Journal of Plant Nutrition and Soil Science, 176, 157, 2013. 